\title{
Content and Language: the Impact of Pedagogical Designs on Academic Performance within Tertiary English as a Medium of Instruction
}

\author{
ANTONIO JiMÉNEZ MUÑOZ \\ Universidad de Oviedo
}

Received: 6 October 2015 / Accepted: 1 April 2016

ISSN: $1697-7467$

\begin{abstract}
This paper offers the results of a study on two English-taught first-year modules at a Spanish Faculty of Economics. Analysing 2010-2015 results allows measuring the impact of the methodological interventions performed on student grades, thus allowing comparisons between their effectiveness. Findings reveal the influence on grades of studentcentred, hands-on methodologies and language remedial interventions, which suggests studying Content-and-Language Integrated Learning and English-as-a-Medium-of-Instruction in terms of their pedagogical practice and not as separate approaches. Ultimately, the study stresses the need to promote language adaptation, student-centredness and independent-learning within bilingual contexts.
\end{abstract}

Keywords: CLIL, achievement control, didactic use of computer.

Contenido y lengua: el impacto de los diseños pedagógicos sobre el rendimiento académico en educación universitaria con inglés como lengua vehicular

RESUMEN: Este artículo ofrece los resultados de un estudio llevado a cabo en dos asignaturas bilingües de primer año en una Facultad de Economía española. Un análisis del rendimiento académico 2010-2015 permite medir el impacto de las intervenciones metodológicas efectuadas y comparar su efectividad. Los resultados revelan la influencia en las notas de los diseños prácticos y centrados en el alumno, y la resolución de problemas de lengua, que sugiere estudiar el Aprendizaje Integrado de Contenidos y Lenguas Extranjeras e Inglés como Medio de Instrucción según sus prácticas pedagógicas y no como dos enfoques separados. Finalmente, el estudio subraya la necesidad de promover la adaptación lingüística, la centralidad del estudiante y el estudio independiente en entornos bilingües.

Palabras clave: educación bilingüe, control del rendimiento, uso didáctico del ordenador.

\section{INTRODUCTION}

Different factors may explain the recent expansion of English-mediated instruction, such as the European Higher Education Area (EHEA) and higher student international mobility. In Australia, 19.8\% of university enrolments are foreign, while in other countries $-14.7 \%$ in Austria, $15.6 \%$ in New Zealand, $16.2 \%$ in Switzerland, and $16.8 \%$ in the United Kingdom - have remained a substantial fraction for years (OECD, 2013: 311). Adding to a tradition of English-taught degrees in Western countries (Wächter \& Maiworm, 2014), 
direct and wider competition for local universities has triggered programmes in English to attract foreign students. Latecomers to language immersion, such as Spain, have shown a recent interest in Content and Language Integrated Learning (CLIL) programmes as the model for bilingualism both in secondary and tertiary education. To some instructors, particularly those in content areas with no experience in bilingual programmes, there is often a misidentification of dissimilar educational approaches such as English as the Medium of Instruction (EMI) and CLIL, and a fundamental lack of training in English for Specific Purposes (ESP) or English for Academic Purposes (EAP). Instructors have noted the tall challenge of teaching content through another language (Airey, 2004), their lack of skills to solve "language-related issues" (Airey, 2013: 64), to anticipate which level of English is required (Jenkins, Cogo, \& Dewey, 2011) and the need to oversimplify linguistic content to facilitate student comprehension (Costa \& Coleman, 2010). Instructors in tertiary education often believe to be teaching their subject under EMI - thus using English as a vehicular language, with no specific language targets - and yet they often find themselves in the need to amend or cater for the linguistic needs of students whose first language is not English (Airey, 2013) or whose "school English" does not meet academic requirements (Erling \& Hilgendorf, 2006: 284). English at university degrees in Spain has been generally considered "as a requisite rather than an expressed learning outcome" (Dafouz, Camacho, \& Urquía, 2014: 3) in the design of bilingual academic programmes, and generally no early adjustments have been made to the approach of already existing Spanish-taught modules.

The negative potential impact on grades and outcomes (Clegg, 2001) of this lack of adaptation is an evident concern. From the instructional point of view, however, many modules have deployed CLIL-related techniques such as language or visual scaffolding, a degree of authenticity through real-life data, a multiple focus on group and interpersonal skills, and a tendency towards active and student-centred learning within a safe learning environment (Mehisto, Marsh, \& Frigols, 2008, pp. 139-141). Some Business instructors have also redesigned their modules, particularly first-year ones, to meet the specific needs of their learners (Hyland 2000). As a result, these modules comply with absolute and variable characteristics for classification under ESP (Strevens, 1988; Dudley-Evans \& St. John 1998), as well as being "goal-directed" and specifying "what exactly it is that students have to do through the medium of English" (Robinson, 1991: 3). These first-year modules work as English-forSpecific-Business-Purposes courses (ESBP), teaching students foundation ESP skills such as interpreting graphs, presenting content, writing short reports and debating micro-skills (turn taking, toning down, holding the floor, etc.), as required for subsequent modules in their programme of studies. There are some credits allocated for independent study for both content and language study. As a result of this set-up, instructors have turned to individual remedial practices in three main areas: instructional design (student-centred/productive vs. passive/receptive methodologies), method of delivery (human vs. machine-mediated), and the balance of ESP skills (theory vs. practice) both for in-class and out-of-class contexts in tasks which simulate target situations in real life (Young, 2006: 35). Unlike in more teacher-led approaches, student-led tasks evidence their language performance, thus enabling to re-contextualize their linguistic needs through ICT-mediated modes (Picciano, Dziuban, \& Graham, 2013), and they ensure that these students develop practical or interpersonal skills in the target language. 
Such context-specific variables may give rise to many potential approaches within the umbrella of either EMI or CLIL modules. For many Spanish content instructors, particularly those in Engineering, EMI entails a stern refusal to teach language and a tendency to evaluate language proficiency above other aspects (Aguilar, 2015); others, such as Nordic instructors in natural sciences, seem to accept more flexibly that linguistic errors from students do not block learning content (Kuteeva \& Airey, 2014). This multiplicity of settings, pedagogies and participant opinions complicates transferring good practice across contexts, participants or institutions if no description of the differentiating instructional designs is offered, but particularly if there is no assessment of the impact of such instructional designs and practices upon academic results. In view of these factors, this paper's research questions are: (1) Do CLIL and EMI offer distinct results in terms of grades? (2) Is the impact of methodological changes relevant in student outcomes? (3) Do students being taught in a foreign language perform better if they are required to be more active and/or independent? (4) Is first-day language level the most determining factor? And, finally, (5) can grades or outcomes be the sole arbiter of the successfulness of pedagogical interventions? These questions are answered in the conclusions, after discussing key findings from the study.

\section{ThEORETICAL FRAMEWORK}

The abundance of online resources to support ESP lessons has made it possible to combine online instruction or independent study with classroom-based delivery under a number of instructional approaches, with hybrid, blended, flipped, and inverted learning as common delivery modes in such bilingual or immersion degrees. There is an implicit consensus "that a blended course combines online learning with traditional face-to-face class activities" in a way in which "between $20 \%$ and $79 \%$ of course content and activities are delivered online" (Arbaugh, 2014: 2). However, these percentages are too ample, which has prompted other models to map variables such as instructor or technology-based delivery and information or practice-based sessions into a number of potential instructional modes (Margulieux, et al., 2014: 2401). The quantified, improved model offered in Table 1 measures Student Time of exposure (ST) to both means of delivery (instructor vs. technology-mediated) and information (transmission vs. practice), and thus it creates five measurable, potential spaces of learning experiences. 
Table 1. Distribution of student time in combined learning experiences.

Delivery via instructor

\begin{tabular}{|c|c|c|c|}
\hline \multirow{3}{*}{$\begin{array}{l}\text { Information } \\
\text { Transmission }\end{array}$} & $\begin{array}{l}\text { Instructor-trans- } \\
\text { mitted }\end{array}$ & $\begin{array}{c}\text { F2F Mixed } \\
\text { (76-100\% ST instructor, } \\
0-24 \% \text { technology) }\end{array}$ & Instructor-mediated \\
\hline & $\begin{array}{l}\text { Lecture Hybrid } \\
\text { (76-100\% ST in- } \\
\text { formation, } 0-24 \% \\
\text { praxis) }\end{array}$ & $\begin{array}{c}\text { Blended } \\
\text { (25-50\% ST instructor, } \\
25-50 \% \text { technology; } 25- \\
50 \% \text { ST information, } \\
25-50 \% \text { praxis) }\end{array}$ & $\begin{array}{c}\text { Practice Hybrid } \\
\text { (76-100\% ST praxis, } \\
0-24 \% \text { information) }\end{array}$ \\
\hline & $\begin{array}{c}\text { Technology-trans- } \\
\text { mitted }\end{array}$ & $\begin{array}{c}\text { Online Mixed } \\
\text { (76-100\% ST technology, } \\
0-24 \% \text { instructor) }\end{array}$ & $\begin{array}{c}\text { Technology-medi- } \\
\text { ated }\end{array}$ \\
\hline
\end{tabular}

Delivery via Technology

The grid in Table 1 can help classify delivery models more accurately, and thus specify their related research and best practices, with a view on their quantitative impact on student achievement, and not subjective aspects of student motivation or perception of language (Kirkgöz, 2009; 2014). Some studies have nevertheless attempted to measure the evolution of language in tertiary ESP contexts. Aguilar and Muñoz (2013) examined empirically the effect that courses in English had on students' foreign language listening competence and grammar proficiency, evidencing higher gains for lower level students - unparalleled in higher-ability students. Others have analysed Business students' academic performance in terms of coursework, suggesting that the language of instruction does not compromise students' learning of academic content (Dafouz, Camacho, \& Urquía, 2014). My own research with Business students (Jimenez Munoz, 2015) confirms such findings, but establishes a detrimental difference in higher bands. Student language progression is remarkable: as per Common European Framework of Reference (CEFR) levels, on average, they move from $\mathrm{B} 1$ to a low $\mathrm{B} 2$ in writing, listening and speaking skills, and to a low $\mathrm{C} 1$ in reading after two semesters of EMI lessons. Although statistically EMI students performed slightly better than their Spanish-taught counterparts, fewer of them achieved honours.

In short, research on academic achievement needs to take methodological aspects into consideration; in this respect, CLIL in particular is fairly open in terms of methods and procedures. Marsh (2006: 31) agrees that while CLIL practice only requires "integrating 
language and subject teaching, various forms of educational success can be achieved where classrooms comprise learners with diverse levels of linguistic competence". This variability in success had been already put forward in connection with micro and macro skills in EAP (Flowerdew, 1995); consequently, rather than taking CLIL or EMI as umbrella terms, studies on student achievement need to differentiate between a number of methodological aspects that model their implementation. In many countries, the arrival of bilingual programmes has come together with the introduction of ICTs in order to deviate from the lecture as the main medium of content delivery, and to better balance theory and practice (Wastiau, et al., 2013). These factors have entailed a significant change in pedagogical designs: in most universities, lecturers are becoming learning facilitators who explain core content in class. Students, in turn, play a remarkably more active role in the classroom and in the construction of their knowledge and language skills, in interaction with rich, ICT-mediated materials outside the classroom.

\section{Methodology}

If bilingual provisions differ pedagogically, research on the impact of each particular instructional practice must be restricted to those elements which are comparable among designs, such as grades. This allows assessing the impact of particular techniques while not judging CLIL, EMI, ESP or EAP approaches as a whole. In the research project detailed below, real-life applications of theoretical approaches are analysed in order to determine their impact on student learning. Particularly, peculiarities of EMI and CLIL, the use of ICTs, and the balance between theory and practice are scrutinized against student grades and linguistic evolution in a number of subsequent first-year groups, in a dual-route (English-taught or Spanish-taught) degree in Economics at a Spanish university.

\subsection{Context of the Study and Participants}

The University of Oviedo (1608) caters for circa 25000 students with over 2000 lecturers in 31 faculties and 150 degrees, 14 of them taught through English. The Faculty of Economics and Business has offered MAs in English since 2004 and, from 2010, to one of the groups in the first two years of the four-year Degrees in Business Administration, Economics, and Accountancy and Finance. The faculty is non-selective, though EMI students are required a $70 \%$ pass grade in English in Spanish University Access Tests, which only assess writing and grammar - and not listening or speaking. Syllabi in EMI and non-EMI routes are identical, as are final assessment tests and marking schemes. EMI and non-EMI lecturers deliver content at the same pace and are strongly coordinated.

Instructors are required either to certify a CEFR C1, or to attest a B2 level and follow two in-house training courses, taught by members of the English department. The courses are in English, and range from advanced pronunciation to presentation skills, IELTS preparation and $\mathrm{C} 1$ conversation; there is formal assessment and, if a $\mathrm{C} 1$ is evidenced in lesson simulations, lecturers are certified. On the other hand, these training courses do not deal with pedagogical issues; for instance, they do not (i) foster student-centred methodologies, 
(ii) offer solutions to language-specific problems, or (iii) give indications as to using ICTs in ways that students may find beneficial.

\subsubsection{The Modules}

This study (see Table 2) analyses data from 2010 to 2015 in two modules: first-semester World Economic History (WEH) and second-semester World Economy (WE). Both are 6 ECTS, 150-hour compulsory modules, with 53 contact hours and an allocation of 97 hours for independent study. Underperformance, when compared to non-EMI groups, and perceived linguistic shortcomings of students have led instructors to devise a number of pedagogical modifications which, while not affecting curricula, have turned their educational design into a heavily revised version of the methodology used before 2010 in Spanish-only modules.

\subsubsection{The Participants}

The English groups in the degree in Economy (2010-2015) have totalled 177 students (102 female, 75 male), from 28 students (2010-2011) to a maximum of 42 first-year undergraduates (2014-2015), being most of them 18-20 years old. With the exception of 14 overseas enrolments, the students come from Spanish secondary schools, which yield a CEFR A2 level of English as a foreign language, according to Spanish educational laws. The background is not promising; the language level of English in Spain is among the lowest in Europe (EUROSTAT, 2013) and 25\% of secondary students fail English in access tests, although $98.2 \%$ are granted access to higher education (Ministry of Education, Culture and Sport, 2014). Students' A2 is very far from the implied requirements of EMI and tertiary education: the ability to "understand extended speech and lectures" and "follow even complex lines of argument provided the topic is reasonably familiar" (Council of Europe, 2001: 27) corresponds to $\mathrm{B} 2$, and is upwardly mobile to $\mathrm{C} 1$ if students are not already reasonably familiar with degree-specific topics.

However, there is evidence that EMI students in this case are over curricular A2, but also that the complexity of the ESP/EAP micro-skills required for EMI modules is beyond the linguistic ability of most students. An analysis of the language skills of 184 students (2012-2014) in their first week found that the overall performance varied from B2.1 in reading to B1.1 in all other skills (Jimenez Munoz, 2015). However, analysing the tasks in the modules, and mapping their implicit skills to CEFR descriptors, student success would require an additional 250 to 750 hours of language tuition, as most tasks would require B2.2 or $\mathrm{C} 1$ proficiency for students to receive full marks. 
Table 2. Outline of methodology for each module.

\begin{tabular}{|c|c|c|c|c|c|c|}
\hline Module & $\begin{array}{l}\text { General } \\
\text { ap- } \\
\text { proach }\end{array}$ & Mode & $\begin{array}{c}\text { Stu- } \\
\text { dent-led }\end{array}$ & $\begin{array}{l}\text { Student- } \\
\text { centred }\end{array}$ & $\begin{array}{l}\text { Scaffold- } \\
\text { ing }\end{array}$ & ICT-mediation \\
\hline $\begin{array}{c}\text { WEH } \\
\text { 2010-2011 }\end{array}$ & EMI & $\begin{array}{l}\text { Lecture } \\
\text { Hybrid }\end{array}$ & No & No & No & None \\
\hline $\begin{array}{c}\text { WEH } \\
\text { 2011-2012 }\end{array}$ & EMI & $\begin{array}{l}\text { Lecture } \\
\text { Hybrid }\end{array}$ & No & No & No & $\begin{array}{c}\text { Core presentations after } \\
\text { lessons }\end{array}$ \\
\hline $\begin{array}{c}\text { WEH } \\
2012-2013\end{array}$ & EMI & $\begin{array}{l}\text { Lecture } \\
\text { Hybrid }\end{array}$ & No & Yes & No & $\begin{array}{l}\text { Core presentation and } \\
\text { selected expansion texts } \\
\text { before lessons }\end{array}$ \\
\hline $\begin{array}{c}\text { WEH } \\
2013-2014\end{array}$ & EMI & $\begin{array}{l}\mathrm{F} 2 \mathrm{~F} \\
\text { Mixed }\end{array}$ & Yes & Yes & No & $\begin{array}{l}\text { Core presentations, } \\
\text { selected texts before } \\
\text { lessons, online practical } \\
\text { tasks after lessons, Twit- } \\
\text { ter-based debates }\end{array}$ \\
\hline $\begin{array}{c}\text { WEH } \\
2014-2015\end{array}$ & CLIL & $\begin{array}{l}\mathrm{F} 2 \mathrm{~F} \\
\text { Mixed }\end{array}$ & Yes & Yes & Yes & $\begin{array}{l}\text { Core presentations, } \\
\text { selected texts, key vo- } \\
\text { cabulary before lessons, } \\
\text { online practical tasks } \\
\text { and English-focused } \\
\text { tasks after lessons, on- } \\
\text { line debates }\end{array}$ \\
\hline $\begin{array}{c}\text { WE } \\
2010-2011\end{array}$ & EMI & $\begin{array}{l}\mathrm{F} 2 \mathrm{~F} \\
\text { Mixed }\end{array}$ & No & No & No & $\begin{array}{l}\text { Core presentations and } \\
\text { additional materials }\end{array}$ \\
\hline $\begin{array}{c}\text { WE } \\
2011-2012\end{array}$ & EMI & $\begin{array}{l}\text { F2F } \\
\text { Mixed }\end{array}$ & No & No & No & $\begin{array}{l}\text { Core presentations and } \\
\text { additional materials }\end{array}$ \\
\hline $\begin{array}{c}\text { WE } \\
2012-2013\end{array}$ & CLIL & Blended & No & Yes & Yes & $\begin{array}{l}\text { Core presentations and } \\
\text { additional materials, } \\
\text { post-session exploratory } \\
\text { resources and tasks }\end{array}$ \\
\hline $\begin{array}{c}\text { WE } \\
2013-2014\end{array}$ & CLIL & Blended & No & Yes & Yes & $\begin{array}{l}\text { Core presentations and } \\
\text { additional materials, } \\
\text { post-session exploratory } \\
\text { resources and tasks, on- } \\
\text { line language tutorials }\end{array}$ \\
\hline $\begin{array}{c}\text { WE } \\
2014-2015\end{array}$ & CLIL & Blended & Yes & Yes & Yes & $\begin{array}{l}\text { Core presentations and } \\
\text { additional materials, } \\
\text { post-session exploratory } \\
\text { resources and tasks, on- } \\
\text { line language tutorials, } \\
\text { project-based content } \\
\text { and debates }\end{array}$ \\
\hline
\end{tabular}




\section{Results}

Tracking changes in educational methodologies and student grades through the years can shed some light upon the impact of the former on the latter. In Table 3 (below), average grade and standard deviation are offered, together with a quantified language level as per CEFR descriptors (Jimenez Munoz, 2014). This is informed from a number of sources; first, an online-based test measuring EAP reading and listening skills on set Economics-related articles, reports and video news; secondly, an interview and a recorded presentation on set topics such as monetization, free trade or World Trade Organization regulations; finally, linguistic grading of ESP coursework and final written exams, which include summarising, defining, paraphrasing, debating and other EAP micro-skills.

Table 3. Results per module and year.

\begin{tabular}{|c|c|c|c|c|}
\hline Module & $\begin{array}{c}\text { No. of } \\
\text { students }\end{array}$ & $\begin{array}{c}\text { Avg. } \\
\text { Grade }\end{array}$ & $\begin{array}{c}\text { Standard } \\
\text { Deviation }\end{array}$ & $\begin{array}{c}\text { Avg. English skills } \\
\text { (CEFR level) }\end{array}$ \\
\hline WEH 2010-2011 & 32 & 81.9 & 2.793 & 92.221 \\
\hline WEH 2011-2012 & 34 & 77.9 & 1.723 & 82.342 \\
\hline WEH 2012-2013 & 36 & 65.3 & 2.548 & 77.327 \\
\hline WEH 2013-2014 & 33 & 75.5 & 1.543 & 75.141 \\
\hline WEH 2014-2015 & 42 & 78.3 & 1.675 & 76.239 \\
\hline WE 2010-2011 & 32 & 66.2 & 1.169 & 92.221 \\
\hline WE 2011-2012 & 34 & 60.9 & 2.738 & 82.342 \\
\hline WE 2012-2013 & 36 & 63.2 & 1.987 & 77.327 \\
\hline WE 2013-2014 & 33 & 64.7 & 1.123 & 75.141 \\
\hline WE 2014-2015 & 42 & 68.8 & 1.328 & 76.239 \\
\hline
\end{tabular}

Taking the average grade as a dependent variable, the 11 non-parametric factors below reveal their impact on student grades. The relative impact of each factor on grades is shown by a factorial correlation analysis for those 177 students (see Table 4).

Table 4. Adjusted R-squared coefficients.

\begin{tabular}{|c|l|c|c|}
\hline Rank & \multicolumn{1}{|c|}{ Variable pair } & R-squared & Adjusted R-squared \\
\hline 1 & Language support $\sim$ Grade & 0.9352 & 0.9350 \\
\hline 2 & Student-led task $\sim$ Grade & 0.8978 & 0.8976 \\
\hline 3 & CEFR level $\sim$ Grade & 0.8881 & 0.8879 \\
\hline 4 & Scaffolding $\sim$ Grade & 0.8777 & 0.8775 \\
\hline 5 & Lecture Hybrid $\sim$ Grade & 0.8679 & 0.8676 \\
\hline 6 & Blended $\sim$ Grade & 0.7921 & 0.7897 \\
\hline 7 & CLIL $\sim$ Grade & 0.6432 & 0.6431 \\
\hline
\end{tabular}




\begin{tabular}{|c|l|c|c|}
\hline Rank & \multicolumn{1}{|c|}{ Variable pair } & R-squared & Adjusted R-squared \\
\hline 8 & EMI $\sim$ Grade & 0.6219 & 0.6216 \\
\hline 9 & Instructor-led $\sim$ Grade & 0.6133 & 0.6131 \\
\hline 10 & F2F Mixed $\sim$ Grade & 0.5881 & 0.5877 \\
\hline 11 & Student numbers $\sim$ Grade & 0.5282 & 0.5254 \\
\hline
\end{tabular}

To complement hard data, a series of interviews with a reduced number of students and the instructors allows further qualitative data to aid in the interpretation of these results, which is also collected through 1-5 LIKERT questionnaires on items such as teacher and student satisfaction, syllabus completion, assessment procedures, and other related factors. These questionnaires included issues related to assessment which, as it will be revealed in the conclusions below, help understanding why focusing on grades can be deceptive if no analysis upon the context and actors of student evaluation is performed.

\section{Conclusions}

By aggregating data from the results in Table 3 and matching these to the methodological modifications exerted upon the modules along the years (see Table 2), some observations can be drawn towards the five research questions listed in the introduction. As to whether CLIL and EMI offer distinct results in terms of grades (see Table 5), it must be noted that, statistically, both approaches yielded very similar results in the years these were implemented.

Table 5. Aggregate results per pedagogical design.

\begin{tabular}{|c|c|c|c|c|c|}
\hline Module & Years & $\begin{array}{l}\text { Avg. } \\
\text { Grade }\end{array}$ & $\begin{array}{c}\text { Variance } \\
(\%)\end{array}$ & $\begin{array}{l}\text { Standard } \\
\text { Deviation }\end{array}$ & $\begin{array}{l}\text { Vari- } \\
\text { ance }\end{array}$ \\
\hline WEH EMI & $\begin{array}{l}2010- \\
2014\end{array}$ & 75.15 & - & 2.152 & - \\
\hline $\begin{array}{l}\text { WEH } \\
\text { CLIL }\end{array}$ & $\begin{array}{l}2014- \\
2015\end{array}$ & 78.3 & $\begin{array}{c}+3.15 \\
(4 \%)\end{array}$ & 1.675 & -0.477 \\
\hline WE EMI & $\begin{array}{c}2010- \\
2012 \\
\end{array}$ & 63.55 & - & 1.954 & - \\
\hline WE CLIL & $\begin{array}{l}2012- \\
2015\end{array}$ & 65.65 & $\begin{array}{c}+2.1 \\
(3.2 \%)\end{array}$ & 1.48 & -0.474 \\
\hline $\begin{array}{l}\text { EMI over- } \\
\text { all }\end{array}$ & - & 69.35 & & 2.053 & \\
\hline $\begin{array}{l}\text { CLIL over- } \\
\text { all }\end{array}$ & - & 71.98 & $\begin{array}{l}+2.63 \\
(3.6 \%)\end{array}$ & 1.578 & -0.475 \\
\hline
\end{tabular}

When comparing student achievement under EMI to that under a CLIL programme with the same syllabus and assessment, CLIL improves EMI results by a meagre $3.6 \%$, as grade aggregates for the years in which either EMI or CLIL were implemented show little 
difference -69.35 to 71.98 marks. These results are in accordance with theoretical discussion on their similarities in actual classroom practice (Lasagabaster \& Sierra, 2010), which hints at the need to observe which particular methodologies are put into practice within these overarching approaches. Towards answering the second research question above, it must be noted that analysing the impact of particular methodological changes may help unearth their relative impact on grades (see Table 6) with greater detail than aggregate comparison among approaches. This is particularly true when tasks are student-led; they performed $7.6 \%$ better if they were more actively engaged in more independent tasks, as opposed to those which were led by the instructor.

In addition, while the student initial language level impacts grades heavily (see Table 4), it is not the most determinant factor; language support and student-led tasks seem to have a marginally greater impact on student grades. Furthermore, students first-day English level according to entry tests was significantly higher in EMI years than in CLIL years (86.3 to 76.2), entailing a $-8.9 \%$ variance for a period in which CLIL student grades nevertheless outperformed EMI students (see Table 5). To answer the last of the research questions, as to whether student grades can be the primary indicator of the successfulness of a bilingual programme under EMI or CLIL, it must be noted that sometime hard data, such as those obtained in university performance reports, can be deceptive if not contextualised pedagogically.

Table 6. Aggregate results per methodology implemented.

\begin{tabular}{|c|c|c|}
\hline Methodology & Avg. Grade & Variance (\%) \\
\hline Lecture Hybrid & 75.03 & - \\
\hline F2F Mixed & 70.22 & $-4.81(6.9 \%)$ \\
\hline Blended & 65.57 & $-4.65(7.1 \%)$ \\
\hline Teacher-led & 68.59 & - \\
\hline Student-led & 74.2 & $+5.61(7.6 \%)$ \\
\hline Teacher-centred & 70.32 & - \\
\hline Student-centred & 70.22 & $-0.1(0.1 \%)$ \\
\hline No scaffolding & 71.28333333 & - \\
\hline Scaffolding & 68.75 & $-2.53(3.7 \%)$ \\
\hline
\end{tabular}

As per Table 6, and with the exception of the inclusion of tasks in which students take the initiative - task-based projects, student presentations or creating topic-focused posters the rest of methodological modifications (such as mixing content delivery through ICT with face-to-face sessions or using language scaffolding in class) seem to have had a negative impact on learning, if any. Needless to say, these seemingly negative results for some of the methodological changes performed need to be interpreted within an informed discussion of the nature of such modifications. Besides, they cannot be judged to be enough of an indicator - not because of their lack of pedagogical considerations, but because generally no extended data about assessment tools were collected. There is typically no indicator in performance reports to gauge whether these methodological changes have been mirrored by correlate changes in assessment procedures. In other words, grades cannot be taken as 
the sole arbiter of the successfulness of a given programme or a pedagogical intervention, merely because the qualitative correlation between teaching and assessment is taken for granted and not studied in detail.

Adding qualitative data from the satisfaction questionnaires and interviews mentioned above may shed some light upon the real significance of these figures. To begin with, the effect of evaluation tools on grades obscures the impact of each of the factors in Table 6 above. In qualitative questionnaires from students, $87 \%$ of them agree that "Assessment has been fair", but $63 \%$ believe that "Exam questions were not following the approach of lessons", and $72 \%$ agree that "Theoretical content exceeds practical tasks in mark weigh". Interviewed about these, the instructors for these modules report that pre-2010 assessment methods have not changed greatly, and that often these do not reflect the approach of lessons, because "Spanish-taught groups must sit the same exam", "Their lessons are theory-oriented", and "Instructors often consider practical tasks as subjective assessment". Secondly, instructors were not lenient towards grammar mistakes and misspellings, since marking schemes for both EMI and non-EMI groups severely penalise accuracy. This may be justifiable for first-year students using their mother tongue, but rather questionable for CEFR A2/B1 freshers. Adding aspects such as leniency (Han, 2015) seems crucial to hold grades as pertinent evidence of success. Finally, the stress on theory of final exams in this case jeopardises significant assessment of student skills. The slightly better results for those students with more a traditional approach (Lecture Hybrid, 75.03) are restricted to a single module (World Economic History) and are justified, instructors report in interviews, because "Tests closely match theoretical content in lessons" and "Student creativity was not required at this stage". As a consequence, students who followed a more hands-on approach to problem-solving in their lessons were penalised by the final theory-leaden exam.

While the need for students to interact and produce output has long been established as a classroom target (Lyster, 2007) there is a persistent mismatch between the practical and creative activities in the Business ESP contexts observed and the way students are assessed. Yet, from 2013-2014 English-taught first-year students have outperformed their Spanishtaught counterparts (52.327 to 48.984 mean grades, including non-sitters). Tentatively, these findings deepen into the importance of introducing linguistic and methodological adaptations in bilingual contexts, particularly when transitioning from General English or non-EMI programmes. Most importantly, however, the subsequent discussion above also makes a case for teaching and assessment models to cohere if grades are to be considered as the main indicator of success within a particular language provision. Therefore, further collaboration is needed among researchers into bilingual education and those focused on assessment and testing in order to detect good practices for educational research to determine the impact of particular approached and methodologies on student learning.

\section{REFERENCES}

Aguilar, M. (2015). "Engineering lecturers' views on CLIL and EMI", in International Journal of Bilingual Education and Bilingualism, 19, 2: 13-27.

Aguilar, M. and Muñoz, C. (2013). "The effect of proficiency on CLIL benefits in Engineering students in Spain", in International Journal of Applied Linguistics, 2, 2, 1-18. 
Airey, J. (2004). "Can you teach it in English? Aspects of the language choice debate in Swedish higher education", in R. Wilkinson (ed.), Integrating Content and Language: Meeting the Challenge of a Multilingual Higher Education. Maastricht: Universitaire Pers, 97-108.

Airey, J. (2013). "I don't teach language: The linguistic attitudes of physics lecturers in Sweden", in AILA Review, 25, 64-79.

Arbaugh, J. (2014). "What might online delivery teach us about blended management education?", in Journal of Management Education, 38, 6: 784-817.

Clegg, J. (2001). "Towards successful English-medium education in Southern Africa", in D. Marsh (ed.), Enhancing English-medium Education in Namibia. Jyväskylä: University of Jyväskylä, 11-13.

Costa, F. and Coleman, J. A. (2010). "Integrating content and language in higher education in Italy: Ongoing research", in International CLIL Research Journal, 1, 3: 19-29.

Council of Europe. (2001). The Common European Framework of Reference for Languages: Learning, Teaching, Assessment. Cambridge: Cambridge U. Press.

Dafouz, E., Camacho, M., and Urquía, E. (2014). "Surely they can't do as well: A comparison of Business students' academic performance in English-medium and Spanish-as-first-languagemedium programmes", in Language and Education, 28, 3: 223-236.

Dudley-Evans, T., and St John, M. (1998). Developments in ESP: A multi-disciplinary approach. Cambridge: Cambridge U. Press.

Erling, E., and Hilgendorf, S. (2006). "Language policies in the context of German higher education", in Language Policy, 5, 3: 267-293.

EUROSTAT. (2013). "Two-thirds of working age adults in the EU28 in 2011 state they know a foreign language", available from: http://ec.europa.eu/eurostat, accessed 1 December, 2015.

Flowerdew, J. (1995), Academic Listening: Research Perspectives. Cambridge: Cambridge U. Press. Han, C. (2015). "Investigating rater severity/leniency in interpreter performance testing: A multifaceted Rasch measurement approach", in Interpreting, 17, 2: 255-283.

Hyland, K. (2000). Disciplinary Discourses. Harlow: Longman.

Jenkins, J., Cogo, A. and Dewey, M. (2011). "Review of developments in research into English as a lingua franca", Language Teaching, 44, 3: 281-315.

Jimenez Munoz, A. (2014). "Measuring the impact of CLIL on language skills: a CEFR-based approach for higher education", in Language Value, 6, 1: 28-50.

Jimenez Munoz, A. (2015). "English as a medium of instruction: Evidence for language and content targets in bilingual education in Economics", in International Journal of Bilingual Education and Bilingualism, 19, 5. http://www.tandfonline.com/doi/10.1080/13670050.2015.1125847.

Kirkgöz, Y. (2009). "Students and lecturers perceptions of the effectiveness of foreign language instruction in a university in Turkey", in Teaching in Higher Education, 19, 1: 81-93.

Kirkgöz, Y. (2014). "Students' perceptions of English language versus Turkish language used as the medium of instruction in higher education in Turkey", in International Periodical For The Languages, Literature and History of Turkish or Turkic, 9, 12: 443-459.

Kuteeva, M. and Airey, J. (2014). "Disciplinary differences in the use of English in higher education: Reflections on recent language policy developments", in Higher Education, 67, 5: 533-549.

Lasagabaster, D. and Sierra, J. M. (2010). "Immersion and CLIL in English: more differences than similarities", in ELT Journal, 64, 4: 367-375.

Lyster, R. (2007). Learning and Teaching Languages Through Content. Amsterdam: John Benjamins.

Margulieux, L. E., Bujak, K. R., McCracken, W. M. and Majerich, D. M. (2014). "hybrid, blended, flipped, and inverted: Defining Terms in a two dimensional taxonomy", in Proceedings of The Hawaii 12th International Conference on Education, 12: 2394-2402. 
Marsh, D. (2006). "English as a medium of instruction in the new global linguistic order: Global characteristics, Local Consequences", in Proceedings of the Annual Conference for METSMaC, 2: 29-38.

Mehisto, P., Marsh, D. and Frigols, M. J. (2008). Uncovering CLIL. London: Macmillan.

Ministry of Education, Culture and Sport, Spain. (2014). "Datos y cifras del sistema universitario español 2013-2014", available from: http://www.mecd.gob.es/prensa-mecd/, accessed 1 December, 2015.

OECD. (2013). Education at a Glance 2013. Paris: OECD Publishing.

Picciano, A., Dziuban, C. and Graham, C. (2013). Research Perspectives in Blended Learning vol. 2. London: Routledge.

Robinson, P. (1991). ESP Today: A Practitioner's Guide. London: Prentice Hall.

Strevens, P. (1988). "ESP after twenty years: a reappraisal", in M. Tickoo (ed.), ESP: State of the Art. Singapore: SEAMEO Regional Centre, 1-13.

Wächter, B. and Maiworm, F. (2014). English-taught Programmes in European Higher Education. The state of play in 2014. Bonn: Lemmens.

Wastiau, P., Blamire, R. K., Quittre, V., Van de Gaer, E. and Monseur, C. (2013). "The use of ICT in education: a survey of schools in Europe", in European Journal of Education, 48: 11-27.

Young, A. (2006). Teaching Writing Across the Curriculum. Upper Saddle River, NJ: Prentice Hall. 